\title{
Intertextuality in the Book of Jubilees
}

\author{
Pieter M Venter \\ Department of Old Testament Studies \\ University of Pretoria
}

\begin{abstract}
Intertextuality in the Book of Jubilees

The second century BCE Book of Jubilees presents the contents of Genesis-Exodus in a new form. This article studies the techniques used in Jubilees 23. It indicates how Psalm 90:10 was used to link the death of Abraham to a declining-inclining scheme of longevity. This scheme was then combined with a heptadic jubilee scheme. To this the author added a Deuteronomistic retributive scheme of sinpunishment-repentance-salvation. On this combination an apocalyptic framework was finally superimposed.
\end{abstract}

\section{INTRODUCTION}

The Book of Jubilees belongs to the pseudepigrapha. It is part of the Ethiopian Canon. The book has only survived in its entirety in classical Ethiopic (Ge'ez). It enjoyed canonical status in the Abyssinian Church and later among the Falashas (the black Jews of Ethiopia). It was probably rendered into Ethiopic very early in the Christian history of that land, perhaps 500 AD (cf VanderKam 1985:112). It was originally written in Hebrew during the middle of the second century BCE. Fragments of the book were found in 18 manuscripts in the caves at Qumran. The oldest of these comes from approximately 100 BCE (cf VanderKam 1985:115).

The book is in essence a re-writing of the materials in Genesis-Exodus 19. It was classified by Vermez as "Rewritten Bible", one of the "parabiblical writings" (Trebolle-Barrera 2000:102), in which we find "rewriting with intent and purpose in mind" (Endres 1987:15). The Book of Jubilees "represents an early Palestinian attempt to theologize the sacred story: the author rewrote and supplemented the tradition so that it would address the community that constituted its audience" (Endres 1987:226). The author's review of critical events in the past was done "in order to expose their significance for understanding his own contemporary political, social, or cultural situation 


\section{Intertextuality in the Book of Jubilees}

(Wintermute 1988:37). He used the existing biblical text of Genesis-Exodus and "adapted it to the exigencies of his era and setting" (Endres 1987:5, n 5).

The focus areas of the book comprise the covenant, retributive justice, sacred persons and places (especially Levi as the transmitter of patriarchal tradition and teacher of righteousness), a "theological concern for time" (Wintermute 1988:38) (especially the dates of the festivals, a calendar of 364 days, and the Sabbath), cult prescriptions, priestly tithes, hostility to surrounding nations, and abhorrence of gentile practices. The book is presented as a divine revelation given to Moses during his forty days and nights on Mount Sinai. This revelation takes place through the agency of an "angel of presence" who dictates to Moses the "tablets of the division of years from the time of the creation of the law and testimony according to their weeks (of years), according to the jubilees, year by year throughout the full number of jubilees, from the day of creation until the day of the new creation ..." (Jub 1:29). ${ }^{1}$ In chapter one it is described how God ordered the angel of presence to dictate to Moses the contents of these heavenly tablets containing what is found in Jubilees 2-50: the chronological system operating between the first and second creations, specific laws on purity and festivals, and the names of chosen persons like Abraham, Isaac and Levi.

From these focuses and the book's probable original Hebrew form it can be deduced that the author was a Jew who lived in Palestine during the second century BCE (cf Wintermute 1988:45). Theories, however, differ on the identity of the author and his affiliations. He could have belonged to "... eine antihellenistische priesterliche restaurative Reformgruppe, die sowohl mit den Asidäern als auch mit der kurz danach entstanden Qumrangruppe in enger historischer Verbindung steht" (Berger 1981:298). He "undoubtedly saw himself as part of a continuous chain of priestly writers going back to Levi" (Wintermute 1988:45) belonging "to the Hasidic or Essene branch of Judaism" (Wintermute 1988:45). The book could have come "... from the pen of a priestly author who wrote during the period immediately after the persecutions of Antiochus IV Epiphanes and the subsequent Maccabean revolt and independence movement" (VanderKam 1985:116). The author can even be "set within a priestly group which held a nascent apocalyptic stance" (Endres 1987:245). While Endres (1987:244) thinks in terms of "a reforming group or movement which views itself as part of the Jerusalem priesthood rather than an opposition party", whose "total separation from Jerusalem cannot be affirmed" (Endres 1987:246), Hempel (2000:188) thinks that Jubilees addressed contemporary concerns at Qumran. It seems likely to Hempel

\footnotetext{
${ }^{1}$ All quotations of Jubilees used, are from the translation of Wintermute (1988), unless differently indicated.
} 
(2000:195) that the book "goes back to the circles from which the yahad emerged as suggested by Knibb and others". She even thinks that "just like there is evidence for a cycle of Danielic and Enochic works, a Jubilees-cycle is attested in the late Second Temple period" (Hempel 2000:192-193).

The author did not use a text of Genesis-Exodus identical with what we know today as the traditional Masoretic Text of the Hebrew Bible. It seems that his text rather stood nearer to the textual tradition of the Septuagint and the Samaritan Pentateuch (cf VanderKam 2001:94). By utilizing a biblical and early Palestinian "text", locating the sacredness of a text not in its precise words, but rather in the sacred story, and in order to make it relevant to the contemporary pressure imposed by Hellenization, "this author expanded and contracted the story at key points, inserted interpretive speeches, added novel expressions of Halakah, and exhorted the Jewish community through an appeal to the examples given by their ancestors" (Endres 1987:250).

\section{READING TECHNIQUES IN JUBILEES}

In articulating a particular understanding of the original document the author used different techniques, such as choosing key points, omission, transformation, halakhic interpolations, addition of material, freely condensing, expurgating, explaining, supplementing and sometimes radically recasting the biblical episodes (cf Wintermute 1988:35). To these Berger (1981:285) adds some other techniques, like "der Gattung des Erzählende Midrasch" in which the extent of the basic writing is changed; framing, giving "das Material eine andere, vorher inm nicht eigene Tendenz", "Ankoppelung von ursprünglich erzählungsfremden Gebotstexten" and dating as a "wichtiges Kompositionsprinzip des Jub". Wintermute (1988:39) understands Jubilees "as a Midrashic reflection on Exodus 24:18" taking scripture as its point of departure, having a homiletical character, paying careful attention to the text, adapting scripture to the present, and presenting halakah and haggada.

Vermes (1975:62) indicated three types of applied exegesis found in Jubilees. The "fulfilment-interpretation" - type is where the subject matter is biblical prophecy in its widest sense, its prerequisite an eschatological outlook, and its model the book of Daniel. According to Endres (1987:213) the prophetic fulfilment texts occur less often in Jubilees. Another type is what Vermes would call "Pure exegesis". Here a scriptural passage contains a word whose exact meaning escaped the interpreter, lacks detail, seems to contradict other biblical texts or its apparent meaning is unacceptable.

Geographical terms often demanded further explanation, e. g. Jub 19:1-6 and 27:19, where the author speaks of the "well of the oath", instead of Beersheba, translating the place name. These changes help to characterize 


\section{Intertextuality in the Book of Jubilees}

the era in which the work was composed and point to the author's desire to present the story without equivocation (cf Endres 1987:221). In cases where the biblical text lacks sufficient detail the author made "Additions". This is clear in the added chronological notations the author made to the events he retold, showing his concern for time and his preoccupation with the sacred calendar (cf Endres 1987:221).

Taking part in this debate started by Vermes on "pure" versus "applied" exegesis in parabiblical works, Halpern-Amaru (1999) identified three more exegetical strategies in Jubilees:

1. "dual functioning" exegesis, which resolves a textual issue and arms polemic;

2. "polemical(ally) weighted" exegesis, which uses gaps in the narrative to promote polemic;

3. "text weighted" exegesis, which clarifies ambiguities or errors.

This terminology acknowledges that there is no ancient exegesis without both an agenda and an intense interest in the details of the text.

Wintermute (1988:37) says that although the biblical text was the author's most important source, "he supplemented it with a considerable amount of traditional material which came to him in either written or oral form". Although Wintermute does not/can not identify all of this traditional material, it can be agreed that the author of Jubilees "has an extensive knowledge of Scripture which enables him to bring to bear widely scattered biblical texts in his discussion of a problem" (Wintermute 1988:40). Also VanderKam (1985:113) is of persuasion that new material was added "that significantly alters the biblical base". The author's "procedure resembles that of the writer of 1 and 2 Chron., who also revised and supplemented a biblical base (1-2 Sam. and 1-2 Kings)" (VanderKam 1985:113).

VanderKam (1985:114-115) indicates the following areas in which additions were made:

1. Chronology. Jubilees' author linked to the final redactor of GenesisExodus' dating a comprehensive chronological system of a 364 day year of exactly 52 week in which all dates fall on the same day of the week every year.

2. He predates the origin of festival and rites to the patriarchal era, giving a prominent position to the festival of weeks. Impressing upon his contemporaries the importance of these festivals "it seems reasonable 
to suppose that by pushing the beginnings of these festivals and rites into more ancient times he meant to underscore their significance and to provide a longer list of exemplary worthies who had obeyed God in these ways" (VanderKam 1985:114).

3. Logical problems in the Genesis-Exodus texts are solved.

4. Extra-biblical stories about biblical characters are used: "Jubilees expands the biblical narrative at many points with material drawn from elsewhere" (VanderKam 1985:115). It is especially the stories about Abraham, Jacob and Levi which undergo noticeable growth.

\section{JUBILEES 23:8-32}

VanderKam (1985:113) remarks that "[n]aturally the greatest interest attaches to those passages which the author altered significantly and to those which he added from extra-biblical sources". It is very difficult, and in most cases impossible, to identify the sources of these passages the author added to his biblical source. Something, however, can be indicated of the techniques used by the author in this regard and the purposes he had in mind.

Jubilees 23:8-32 is one of those passages in which the author altered and added to the biblical source text. In the source text (Gn 25:1-6) a report on Abraham's marriage with Keturah and the offspring he had with her, is followed by a report on Abraham's death and burial (Gn 25:7-11). This is followed by a list of Ishmael's descendants (Gn 25:12-18). In Jubilees the first passage on Keturah and the third section on Ishmael's posterity are left out totally. The information on the death of Abraham reported in Genesis 25:7-11 is repeated in Jubilees 23:1-7.

In Jubilees the report on Abraham's death (23:1-7) follows upon information on Jacob's second blessing in Jub 22:25-30. In Jubilees 23:8 a new section starts on general decline in longevity. This information is not found in the Genesis text. It is, however, linked to the information in Genesis 25:7-8 that Abraham lived a total of 175 years. The following section in Jubilees $23: 8-32$ is marked by several additions to the Genesis text. Endres (1987:197) indicates this "eschatological interpretation of Israel's history" in Jub 23:9-32 as an original additional composition added by the author in his retelling of the narrative.

The passage in Jub 23:8-32 is an exceptional layered text. Analysis of this sections shows that not only four types of addition are found in this section, but that they are also dovetailed into each other. First, the author linked Abraham's age at his death to a heptadic scheme of Jubilees. Secondly 
he used Psalm 90:10 to rectify his scheme and accommodate the role of sin in history. He indicates a declining-inclining development in human longevity. On this rectified scheme he superimposed a Deuteronomistic retributive scheme of $\sin$ and salvation. To all of this he finally added "his most extended eschatological reflections" (VanderKam 2001:57) and set his composition in an apocalyptic context. This paper proposes that Jub 23:8-32 should be read and understood in terms of this superimposing of different schemes in one passage.

\section{JUBILEES' HEPTADIC SCHEME}

Wintermute (1988:35) gives the following outline of the Book of Jubilees:

$\begin{array}{ll}1 & \text { Introduction } \\ 2-4 & \text { Creation and Adam stories } \\ 5-10 & \text { Noah stories } \\ 11: 1-23: 8 & \text { Abraham stories } \\ 23: 9-32 & \text { Digression on Abraham's death } \\ 24-45 & \text { Jacob and his family } \\ 46-50 & \text { Moses stories }\end{array}$

In this delineation chapter 1 (Introduction) and chapter 23:9-32 (Digression on Abraham's death) are marked off by Wintermute (1988:35) "because they are two sections in which the author looks beyond the time of Moses to describe what will happen in the distant future". To attain this purpose the author of Jubilees used a technique of superimposing four different schemes the one upon the other.

The information in the source text of Genesis 25:7-8 that Abraham lived a total of 175 years is literally repeated in Jubilees $23: 8$. This indicates explicit intertextuality between the passages in Jubilees and Genesis. Implicit intertextuality between this chapter in Jubilees and the biblical text is found in several cases. The long life indicated in Jub $23: 9$ and 27 reflects the genealogy of Genesis 5. Traditional condemnation formulas used in Jub 23:22-23 agrees with formulas found in the Bible (cf VanderKam 2001:58). The idea of nations who have no mercy or grace in Jub 23:23 repeat Jeremiah 6:23. The call to be saved from the hand of the sinners in Jub 23:24-25 agrees with the language and motifs used in Trito Isaiah (cf Endres 1987:58). The description of seniors and young people in Jub 23:28 agrees with the ideas in Isaiah 65:20. The idea in Jub 23:31 that their bones will rest in the earth and their spirits will increase joy, is also found in Isaiah 66:14. The expression that God will show mercy to hundreds and thousands, to all who love him (Jub 23:31) is the same expression used in the Decalogue in Exodus 
20:6 and Deut 5:10. All of this indicates what VanderKam (2000b:278) calls "biblically saturated language".

Dialogistic intertextuality can be indicated in Jub $23: 8,11$, and 12 . The numbers of Abraham's years, indicated in the Genesis text as one hundred seventy-five years is repeated in Jubilees using total different numbers and units: three jubilees and four weeks of years. Using basic heptadic units the Book of Jubilees converts 49 years into one jubilee unit consisting of seven week years. Three jubilees therefore are $3 \times 49=147$ years. Four weeks of years is $4 \times 7=28$ years. This adds up to the 175 years presented in the Genesis text.

The Book of Jubilees pretends to be a revelation given to Moses on the mountain. It reveals "what (was) in the beginning and what will occur (in the future), the account of the division of all of the days of the Law and the testimony" (Jub 1:5). In the final chapter the revealing angel of the presence closes his account at "forty-nine jubilees from the days of Adam until this day and one week and two years" (Jub 50:4). That comes to 2410 years, with 40 years outstanding (Jub 50:4) before Israel crosses over the shore of the land of Canaan. After that 50 jubilee units will be completed (2450 years). Slight confusion is created by the information in Jub 1:27 that this overview of history is from the first creation until God's temple is built on Zion, while in 1:29 the heavenly book dictated to Moses reveals the days from the day of the creation until the day of the new creation. Going beyond the biblical text, however, the author dated the significant events in Israel's history as outlined in Genesis and Exodus with exact precision according to a 49 year scheme. This scheme works with the units of "jubilees", "week years" and "years". The precise dating of festivals connected by the author to specific events in history seems to have been of great concern for the writer.

The name of this Jubilee system comes from the command in Leviticus 25 to have a Sabbath year every seventh year and a jubilee after every seven Sabbath years. VanderKam (2000a:169) indicates that the author of Jubilees actually used a tradition of sabbatical weeks and jubilees that goes back to the Hebrew Scriptures. Indication of this tradition is found in the priestly creation story in Genesis 1, the sabbatical legislation in the Covenant Code (Ex 23:10-11), the more extended sabbatical prescriptions in the Holiness Code (Lv 25:2-7), and seventh year rules in the Deuteronomic Code (Dt 15:111). The sabbatical year is brought into connection with Israel's history in Lv 26:34-35. The use of weeks and jubilee units for chronological purposes is found in Jeremiah 25 and 29, Daniel 9:24-27, the Apocalypse of Weeks (1 Enoch 93:1-10; 91:11-17), the Animal Apocalypse (1 Enoch 85-90) and in Jubilees. According the Endres (1987:4), this "scheme resembles the 
calendar presupposed by many priestly sections of the Pentateuch, as well as in other sacerdotal writings such as Ezekiel, Haggai, Zechariah, Ezra, Nehemiah, and Chronicles".

VanderKam (2000a:177-8) comes to the conclusion that:

1. The biblical laws about sabbatical and jubilee years were combined with Jeremiah's prophecies already in the biblical period (cf 2 Chr 36:21 \& Dn 9). They stand at the beginning of the tendency to use these units to measure and divide longer chronological periods of history.

2. The time spans measured in this way differ considerably between authors. It can be applied to all of history, long stretches of biblical and post-biblical history, the earliest part of history, or even the last part of history.

3. Although the authors do not dwell on the purpose of their using these chronological schemes, it can be deduced that it was used to indicate that the past is orderly and calculable because it has been arranged by God. Therefore, the future too can be discerned and one can see one's own place in the divine plan of history. Secondly, the particular language of Sabbaths/weeks and jubilees had the advantages not only of being familiar markers of longer units of time but also came with richly suggestive associations such as the themes of redemption, freedom, release, restoration, judgment and pardon. These could certainly be put to good use both for historical analysis.

In Jubilees the use of this heptadic system of jubilees, weeks-of-years, and years, is linked to the sabbatical system used many times by the author in his book. Following Jaubert, Berger (1981:283) thinks that "[d]ie Bewahrung des Sabbats ist das Hauptmerkmal des Kalenders des Jub". For Jubilees much more is intended here than mere calculation and fixing of dates. Jubilees' chronology "makes a crucial theological statement expressing the author's understanding of biblical history" (VanderKam 2001:94). He uses "a framework of conscious and distinctive chronology" (Endres 1987:4) for reconstructing the biblical history. The author uses this older tradition of sabbatical and jubilee units according to his own understanding of them "to document a profound overall meaning for the early biblical history" (VanderKam 2000a:169). 
Leviticus 25 imposes that alienated land is to be restored to its original owners and Hebrew slaves set free in the fiftieth year. In Jubilees the Israelite slaves freed from their bondage in Egypt return in the fiftieth jubilee period to their own land allotted to the offspring of Shem during the division of the earth between Noah's sons (Jub 8:12-21) but seized from them by Canaan (Jub 10:27-34). As freed slaves they return to their legitimate ancestral territory. Although Lev 25 has the individual in mind, Jub applies it to the whole nation. According to VanderKam (2001:96) "the seemingly tedious chronological notes that saturate the book lead to a large conclusion in which the exodus and conquest are interpreted as paradigmatic or jubilean events".

This is linked to another issue. In Jubilees a pertinent choice is made for the solar calendar. In Jub 6:36 the angel of presence commands Moses to reject the lunar calendar used by the nations "because it is corrupt (with respect to) the seasons and is early from year to year by ten days". This resistance to a month calendar is a continuation of the Seleucidic calendar (cf Berger 1981:283). The solar calendar consists of 364 days divided into 52 weeks. Each quarter consists of exactly 13 weeks of 91 days.

One of the characteristics of this type of calendar is that a specific date will always fall on the same day of the week. Although Jubilees never indicates the day of the week on which any date falls, it can be deduced from related sources that the first of the year always falls on a Wednesday. In Genesis 1 it was on the fourth day of the week on which the sun, moon, and stars were created (cf VanderKam 2001:99). The solar calendar also guarantees that the religious festivals will always be held on the same day and the exact time ordained for them. To prevent any Sabbath to be replaced by any other festival a calendar of 364 days is used so that all dates are fixed and every festival is fixed to specific days. The variable lunar calendar "would lead to a misdating of the sacred times and thus a violation of the order that God had created" (VanderKam 2001:98). In the mind of the author the regular sequence of times and the celebrating of the religious festivals is part of the covenantal agreement between God and Noah. Even more than that, laws and stipulations for religious festivals found in the rest of Exodus and the books of Numbers and Leviticus are retrojected to a much earlier time in Jubilees, not only giving to them an earlier historical origin, but also providing them with an authoritative basis already fixed in the heavenly tablets revealed and dictated to Moses. The use of the solar calendar therefore became an instrument in Jubilees to provide heavenly authority to the dates of religious festivals. 


\section{JUBILEES' LONGEVITY SCHEME}

The author of Jubilees is especially fond of Abraham, Jacob and Levi. He therefore expanded their narratives (cf VanderKam 1985:115). Abraham's death at a relative short age of 175 years, however, presented a problem to the author. Compared to the long lives of the ancestors in Genesis 5 (referred to in Jub 23:9 and 27) the short life of Abraham does not make sense.

Psalm 90:10 presented the solution to the author's problem. In Psalm 90 the brevity of man's life is linked to his sin and to God's wrath. Although his jubilees scheme indicated the order of history, the author has to amend his scheme by acknowledging the effect sin has on history. Psalm 90 links sin to longevity and Abraham's relative short live must be understood in those terms.

The antediluvian ancestors mostly lived for more than 900 years according to Genesis 5. This is recalculated in Jub 23:9 in heptadic terms as 19 jubilees of years (931 years). The age of the generations then started to decline. Psalm 90:10 reads "The days of our life are seventy years, or perhaps eighty, if we are strong; even then their span is only toil and trouble." This is cited in Jub 23:15: "But behold, (as for) the days of our lives, if a man should extend his life seventy years or if he is strong (for) eighty years, then these are evil. And there is not any peace in the days of this evil generation." This is calculated in Jub 23:12 in terms of the jubilee system as "a jubilee and a half" (73.5 [= 73 1/2 cf VanderKam 1985:132] years).

The rest of the passage in Jubilees 23:8-32 deals with human evil and divine recompense. It extends on the "toil and trouble" in Ps 90 and links the circumstances where there is no peace, to the idea in Ps 90 that the brevity of life is due to God's wrath. Words like plague, wound, affliction, evil report, sleet, hail, frost, fever, chills, stupor, famine, death, sword, captivity, and suffering, are used in Jub 23 to depict the short lived life. Not only personal discomfort will be experienced, but on cosmological scale the land will be corrupted. Beast, cattle, birds, and all of the fish of the sea will be destroyed on account of the sons of man (Jub 23:18). Man's iniquities and secret sins causing God's wrath in Psalm 90 are linked to pollution, fornication, contamination, and abomination (Jub 23:14, 17).

Against this background the problem of Abraham's relative brief life span is explained. Although "Abraham was perfect in all of his actions with the Lord and was pleasing through righteousness all of the days of his life" (Jub 23:10), he did not complete four jubilees (196 years). This is due, not to the perfect Abraham's actions, but to the increasing human wickedness after the deluge (Jub 23:9). Abraham is the victim of the evil of his people. Psalm 90 depicts inequity and sin as corporate guilt. Abraham is part of the downward 
trend in longevity. Although perfect, he can not escape from the ordeal brought about by human sin. To Moses is revealed (Ps 90 is ascribed to Moses in the heading of the psalm!) that God's wrath is manifested in the brevity of life. Psalm 90 is therefore quoted to link Abraham's death to evil and the author's view on the result of sin on human history.

The author, however, did not stop there with his rectifying of the jubilees scheme. The longevity of a jubilee and a half represents a turning point in history. Psalm 90 indicates the lowest point in the scale. From then on a slow increase will occur in longevity until it approaches a thousand years (Jub 23:27) again. The author does not only identify the group in his time who are the culprits (those who "have forgotten the commandments and covenant and festivals and months and Sabbaths and jubilees and all of the judgments"- Jub 23:19), but also those who will bring a turning point in history ("children will begin to search the law, and to search the commandments and to return to the way of righteousness" - Jub 23:26). Around the axis of the law he can draw a graph of decline and incline in human history.

For this reformulation he used the retribution scheme of Deuteronomy of decline in sin and punishment and incline in penitence and salvation. Built on that scheme he can complete his reflection on history and also project hope into his jubilee scheme.

\section{JUBILEES' USE OF A TRADITIONAL RETRIBUTIVE SCHEME}

The inverted parabolic line is based on the retributive scheme found in Deuteronomy. This can be indicated as dialogic intertextuality. Jub 23:(14)1631 is also structured according to "Deuteronomistic Patterning" (Endres 1987:53). A retributive historical schema consisting of the elements sin, punishment, penitence and salvation is imposed upon the events between creation and new creation. This pattern is found in Deuteronomy 31-34, especially in Deuteronomy 32:1-43. Historical summaries following this pattern are also found in Psalms 78, 105, 106, 135, 136; Ezra 9; Nehemiah 9:5b-37; Ezekiel 16 and 20; Daniel 2:1-49, 7:1-28, 9:4-19 and 11:14; Ecclesiasticus 4449; the Animal Vision (1 Enoch 89:59-90:19); Apocalypse of the Week (1 Enoch 93:1-10); Tobit 14:4-7; Cairo Damascus Document 1:3-12, 2:14-4:12, 5:20-6:11 and Jubilees 1:7-18.

The passage in Jub 23:16-31 consists of the following sections: $\sin$ (23:16-21); punishment (23:22-25); penitence (23:26), and salvation (23:2731). Halpern-Amaru (1994:52) indicates even a "Doppelschema" here where the retribution scheme is repeated twice: $\sin (14-17)$, punishment (18-19), 
failed restoration (20); $\sin (21)$, punishment (22-25), repentance (26), and restoration (27-31).

The author of Jubilees, therefore, not only retrojects the laws and religious festivals from the rest of the Pentateuch into the early GenesisExodus events, but also the retributive Deuteronomistic scheme. He interprets his heptadic history also in terms of the covenantal stipulations of retribution. His reckoning of Abraham's years in terms of jubilee years forced him to compare his years with those of the ancestors. To explain the relative short years of Abraham he had to bring sin into play and expand his heptadic history with the retribution scheme found in the much later Deuteronomic phase. This scheme will, however, make it possible for the author to end on an eschatological note of redemption.

The element of sin is addressed in Jub 23:16-21. According to HalpernAmaru (1994:52) this section already starts in 23:14. Verse 18-19 refers in her mind to punishment and verse 20 to a failed restoration. Generally it is revealed that bitter social conflict would occur, as well as catastrophes in nature and even civil war. The theme running through the description of all of these is the abandoning of the Torah's ordinances, specifically those on the festivals, Sabbaths and jubilees. According to Endres (1987:54) concern for "correct observance of the calendar emerges in the author's interpretation of history as well as in the structuring of the narrative." Although there are a horde of possible situations to which these descriptions can be applied to, it can be supposed without any hesitancy that the author is contemporizing the biblical text, applying it to his second century BCE situation. He identifies those people and their acts who clashes with his ideology on the revealed truth. The author not only encourages his readers to learn the commandments, follow moral teachings and execute ritual laws, but to also interpret contemporary events in the light of scripture.

In the section on punishment (23:22-25) the author draws on a wide variety of biblical traditions and citations. Punishment mainly takes the form of oppression brought by a foreign nation. The author uses different biblical motifs and traditions to articulate the circumstances of the fourth and fifth decade in Palestine during the second century BCE. Traditional phrases used for similar attacks by foreign nations, like those found in Deuteronomy 28:4950; Jeremiah 6:23 and Psalm 79:1-3, are used as appropriate descriptions for the fate of the author's contemporaries.

The turning point in history (Jub 23:26) is depicted in terms of the reversal of the abandoning of the Torah described in Jub 23:16-21. Return to the law and searching after the commandments bring reverse in human history. Study of the revealed law, and "adherence to Torah is the constitutive 
aspect of covenant renewal" (Endres 1987:59). The internal strife, inter alia between the generations, described in the section of $\sin$ in Jub 23:16-21 (cf Jub 23:16 and 25), is reverted. The children start out the inquiry into God's laws.

In the author's description of the future salvation (23:27-31) Trito Isaiah (Is 56-66) played a large role. Using the standard apocalyptic phrase "in those days", the author sees the results of the return to the Torah as future salvation. Although not quoting directly, motifs from Isaiah 65 are used to depict the salvation. Two motifs are used: children will become a hundred years old before they die (Is 65:20), and the lamb and the lion will lie together in peace (Is 65:25).

The children in Jub 23:16 reminds VanderKam (1985:135) of 1 Enoch 90:6-7

in which, in a similar context, a group is presented under the youthful image of lambs among sheep. The people in question are probably the pious ones (Hasidim) who are mentioned in the first half of the second century $B C$ and from whose circles the Qumran community was later to develop. The following verses are best interpreted against the backdrop of events before and during the persecution of Jews by Antiochus IV Epiphanes and his forces.

The addition of this section advances, according to Endres (1987:62) "the program of Jubilees both by interpreting the patterns in Israel's history, and by providing direction and motivation for the community addressed by the author". It connects the issue of obedience to the commandments and execution of religious duties propagated by the author of Jubilees to his overview of the history formulated in terms of jubilee years and retribution. The evil generation has "forgotten the commandments and covenant and festivals and months and Sabbaths and jubilees and all of the judgments" (Jub 23:19). VanderKam (2001:58) summarises it as follows: "Jubilees' standards govern what violation of the covenant means and calendrical issues are in the forefront".

\section{JUBILEES' ESCHATOLOGICAL EXPECTATION}

In Jubilees 23:8-32 an eschatological perspective is found. The expectation that an "end time" will come when people will start to search the law and their days will begin to increase and grow longer (Jub 23:27) even approaching a thousand years (Jub 23:27) is depicted in typical eschatological language sketching an idyllic time when all affliction and torment will be replaced by a time of peace. Typical eschatological language is used. Their days will 


\section{Intertextuality in the Book of Jubilees}

approach a thousand years (Jub 23:27). No one will even be old, because they will be called infants and children (Jub 23:28). There will be no Satan or evil (Jub 23:29). It will be the days of blessing and healing (Jub 23:29,30). The enemies will be judged and driven out (Jub 23:30). Even though their bones will rest in the earth, their spirits will live (Jub 23:31).

The question to be asked is whether we are dealing here with apocalyptic ideas or with mere eschatological thinking. Davenport (1971) analyzed passages in Jubilees that either function eschatologically or contain eschatological content. He identified Jub 1:4b-26, 27-28 and 23:14-31 as passages whose function is explicitly to teach matters of eschatology. Davenport's form and redaction study of the book of Jubilees indicates that different redactors collaborated in the writing of the book. There are not only various strata in the book, but these eschatological passages should also be read on different levels. The eschatological poem in Jub 23:24-31 was inserted in the prose section of Jub 22-23 by a redactor ${ }^{2}$ to indicate "that he understood his own day as the eschatological period and that he saw the prophecies of the poetry being fulfilled in his day" (Davenport 1971:34).

In Collins's (1979b:28) judgment, however, Jub 23 contains 13 out of the possible 27 characteristics of Jewish apocalypses. Despite the fact that Jub 23 is not an independent composition, the passage is typically apocalyptic in contents and "must be included in the list of apocalypses" (Collins 1979b:32). Collins (1979a:14, cf Collins 1979b:22) therefore classifies Jub 23 as a "Historical apocalypse with no other worldly journey". Collins (1979b:22) remarks that all Jewish "apocalypses which do not have an otherworldly journey contain an ex eventu prophecy of history". Although the revelation usually involves a vision, the discourse of the angel of presence with Moses excludes a vision (cf Collins 1979b:24).

Nickelsburg (1972:31-33, 46-47) also characterized the passages in Jub 1:7-29 and 23:11-31 with its focus on the future as apocalyptic. Endres (1987:201) describes this passage as a "historical apocalypse because it displays a lively interest in the development of history". Using the typical pattern of sin, punishment, turning point and salvation, often found in the deuteronomistic and Levitical literature, and also used in apocalyptic literature, the author could present an apocalyptic vision for the community of his time. $\mathrm{He}$ "skilfully combined illusions to the contemporary situation of tension caused by the temptations to assimilation in Palestine, with a vision of the future outcome of the struggle between those who remain faithful and those who do not" (Endres 1987:201).

\footnotetext{
${ }^{2}$ Called $R_{1}$ by Davenport (1971:34).
} 
When Jub 23 is compared to Jub 1 it becomes clear that Jub 23:11-31 does not use the same type of cosmological concepts as Jub 1:5-19. Jub 1:23-29 gives information on a cosmic transformation. In Jub 23 an ideological new age is predicted without a Satan or evil destroyer (Jub 23:29). Although no bodily resurrection is portended, a spiritual continuation is foreseen. All of Israel's history is painted in the eschatology of chapter 1 . The presentation of eschatology in Jub 23 narrows the focus to a detailed description of a postexilic period. Both chapters use the same Deuteronomic pattern. In Jub 23 the author develops the central motif of the eschaton around a reconstructed version of the Deuteronomic concern into a universal history around the theme of longevity of lifespan (cf Halpern-Amaru 1994:51). In the place of exile and return "the author sets another kind of physical return as the key feature in a multifaceted restoration: mankind gradually regains the longevity it had lost at the Flood such that by the end of time, when righteousness is totally restored, the "days of man" again "approach a thousand years" (23:28) (Halpern-Amaru 1994:53). The substitution and introduction of the longevity theme makes sense. "It provides the means for preserving the biblical motif of a "paradise lost and regained", while avoiding the biblical Land theology that is appropriate to the writer's post-exilic perspective" (Halpern-Amaru 1994:53).

If the passage is read as apocalyptic, rather than eschatologic, two problems arise in Jub 23:30 and in Jub 23:31. In Jub 23:30 the phrase "the Lord will heal his servants" is paralleled with the sentence "and they will rise up and see great peace". Nickelsburg (1972:22) rejects the interpretation that this verse refers to bodily resurrection, as it is not an independent element of the deuteronomistic retribution pattern. For Endres (1987:60) the phrase "remains slightly ambiguous". It refers to some type of expectation the author expected in his time. Although part of the retribution cycle, speculation on this individual element of resurrection would arise only when it did not materialize. Both therefore choose for an eschatological interpretation.

The other problem is found with the idea that "their bones will rest in the earth, and their spirits will increase joy" (Jub 23:31). Wintermute $(1988: 102 \mathrm{n} \mathrm{p}$ ) indicates two possible interpretations to this phrase:

It could be understood as a description of spirits which remain conscious and aware of post-mortem events while their bones rest in peace. It could also be understood as an example of poetic hyperbole, describing those who die with assurance that justice has been done. They are portrayed as joyous dead who lie in the earth contented with God's certain vindication of the righteous. 
VanderKam (1985:135) deduces from the context that "no resurrection is meant here. Military action may be intended". The mention of "spirits that will be happy" (as translated by VanderKam 1985:135) is understood as "[a]n immortality of sorts [that] is clearly envisaged but not a physical one" (VanderKam 1985:135).

A question that comes to mind is whether all of the book of Jubilees can be read as an apocalypse? For Endres (1987:4-5, n 5) the revelatory schema presenting the contents of Jubilees as revealed by an angel "seems sufficient to classify Jubilees as an apocalyptic work". John Collins (1979b:32), however, sees Jubilees as a "borderline case for the apocalyptic genre" and "the book as a whole is clearly not an apocalypse". Collins (1984:63-67) based his viewpoint on the fact that the generic framework of Jubilees is that of an apocalypse where revelation is mediated through an angel to an honoured person of the past, while the laws included in the work are characterized by the inevitability of their predetermined judgment. The laws are also guidelines for the conflict between angels and demons, apocalyptic ideas like revelation, eschatology, and good and evil spirits are present in the work. Genesis itself has no eschatological perspective. Only some of Jacob's blessing in Genesis 49 was interpreted by some as eschatological (cf VanderKam 2001:57). The mode in all of Jubilees is, however, that of apocalypse. Lange (1999:25-38) argues against the tendency to classify Jubilees as an apocalyptic book. He indicates that the allegorical dream (a characteristic feature of many apocalypses) is generally avoided in the book.

Another issue linked to the question of eschatologic or apocalyptic, is the question of the time in which or for which the book was written. Does the author hint at the time and circumstances of his own time, or does he verbalize the expectations of his time? Reformulating the biblical text to meet his particular objectives, one of his primary goals according to VanderKam (2001:93) "was to make the ancient text speak more directly to contemporary concerns". VanderKam (2001:134) finds in the mentioning of those who begin to search for the law (Jub 23:26) and the metaphors of youth and newness (Jub 23:28), indications to "one or several movements that arose in Israel early in the second century BCE". VanderKam (2001:134) is, however, quick to point out that "the future for Israel should be distinguished sharply from what the writer predicts for the nations". While the end time has already come for Israel, the nations are still awaiting the judgment passed on them. This indicates a continuation of eschatological thinking, but also the early development of apocalyptic thinking. 


\section{CONCLUSION}

When rewriting the history of Israel in Genesis-Exodus the author used a large array of techniques. Jubilees 23:8-32 presents some insights into this masterly reworking.

Dealing with the particulars of Abraham's death in Genesis 25:7-11 the author takes up the opportunity to present his viewpoint on the theological meaning of Israel's history between creation and Moses' receiving of the law at Sinai. He firstly sees history in terms of a heptadic jubilee system where everything is ordered according to the directions of the law on Sabbaths and festival days. Against this background he understands history as a declininginclining development hinted at by the information on longevity found in Psalm 90 , but secondly illustrated in the traditional Deuteronomistic retributive scheme of sin-punishment-repentance-salvation. On this scheme is based the author's eschatologic-apocalyptic expectation that the day will come when all will be obedient to study the law of God.

\section{Works consulted}

Berger, K 1981. Unterweisung in erzählender Form: Das Buch der Jubiläen. Jüdische Schriften aus hellenistisch-römischer Zeit, Band II. Gütersloh: Gütersloher Verlaghaus Gerd Mohn.

Collins, J J 1979a. Introduction: Towards the morphology of a genre. Semeia 13, 120.

Collins, J J 1979b. The Jewish apocalypses. Semeia 13, 21-59.

Collins $\mathrm{J} J$ 1984. The apocalyptic imagination: An introduction to the Jewish matrix of Christianity. New York: Crossroads.

Davenport, $G$ L 1971. The eschatology of the Book of Jubilees. Leiden: Brill.

Endres, J C 1987. Biblical interpretation in the Book of Jubilees. Washington, DC: Catholic Biblical Association of America. (The Catholic Biblical Quarterly Monograph Series 18.)

Halpern-Amaru, B 1994. Rewriting the Bible: Land and covenant in post-biblical Jewish literature. Valley Forge, PA: Trinity Press International.

Halpern-Amaru, B 1999. The empowerment of women in the Book of Jubilees. Leiden: Brill.

Hempel, C 2000. The place of the Book of Jubilees at Qumran and beyond, in Lim, T H (ed), The Dead Sea scrolls in their historical context, 187-196. Edinburgh: T\&T Clark.

Lange, A 1997. Divinatorische Traume und Apokalyptik im Jubiläenbuch, in Albani, Matthias, Frey, Jörg \& Lange, Armin (eds), Studies in the Book of Jubilees, 25-38. Texte und Studien zum antiken Judentum, vol 65. Tübingen: Mohr Siebeck.

Nickelsburg, G W E 1972. Resurrection, immortality, and eternal life in intertestamental Judaism. London: Oxford University. 
Trebolle-Barrera, J 2000. Qumran evidence for a biblical standard text and for nonstandard and parabiblical texts, in Lim, T H (ed), The Dead Sea Scrolls in their historical context, 89-106. Edinburgh: T\&T Clark.

VanderKam, J C 1985. The Book of Jubilees, in De Jonge, M (ed), Outside the Old Testament, 111-144. Cambridge: Cambridge University Press.

VanderKam, J C 2000a. Sabbatical chronologies in the Dead Sea scrolls and related literature, in Lim, T H (ed), The Dead Sea scrolls in their historical context, 159-178. Edinburgh: T\&T Clark.

VanderKam, J C 2000b. Biblical interpretation in 1 Enoch and Jubilees, in VanderKam, J C, From revelation to the to canon: Studies in the Hebrew Bible and second temple literature. 276-304. Leiden: Brill.

VanderKam, J C 2001. The Book of Jubilees. Sheffield: Sheffield Academic Press.

Vermes, G 1975. Post-Biblical Jewish Studies. Leiden Brill.

Wintermute, O S 1988. Jubilees (2nd Century BC): A new translation and introduction, in Charlesworth, $\mathrm{J} \mathrm{H}$ (ed), The Old Testament pseudepigrapha, vol 2, Expansions of the "Old Testament" and legends, wisdom and philosophical literature, prayers, psalms, and odes, fragments of lost Judeo-Hellenistic works, 35-142. New York: Doubleday. 